\title{
Radiation Survey Around Crude Oil Pumping Stations in the Sudan
}

\author{
Elsadig Gumaa ${ }^{1}$, Amged Tageldein ${ }^{2}$, Fareed Fadlallah ${ }^{2}$ and Hajo Idriss s $^{2,3}$ \\ ${ }^{1}$ Sudanese Nuclear \& Radiological Regulatory Authority (SNRRA), Khartoum, Sudan \\ ${ }^{2}$ Sudan Atomic Energy Commission(SAEC) \\ ${ }^{3}$ Committee on Radiation and Environmental Pollution Protection, College of Science, Al Imam Mohammad Ibn Saud \\ Islamic University, Riyadh 11642, Saudi Arabia \\ E. mail: sadiggumaa@gmail.com
}

\begin{abstract}
Safety and health in the workplace are important for the welfare of both worker and public. Hence measurement of radiation doses around crude oil pumping stations were carried out for the purpose of radiation protection. Hand held radiation survey meters RDS -200 and Polymaster have been used for radiation dose measurement. The order of radiation level in investigated areas showed the following trends: Port Sudan $>$ Alelafoon $=$ Jabal Um Ali $>$ Wd shalayee $>$ Mosmar. The average level of radiation dose $5.64 \mu \mathrm{Sv} / \mathrm{y}$ was examined and compared with the recommendations of international organizations concerned with radiation safety. The overall annual effective dose for the workers appears to be negligible compared with the allowable limit of $1.0 \mathrm{mSv} /$ year set by ICRP. From the human health point of view, this study showed that there was no health risk to the workers and public due to radiation exposure.
\end{abstract}

Keywords: Radiation, annual effective dose, RDS-200, crude oil, pumping stations.

\section{Introduction}

Radiation plays an important and vital role in our everyday live. Everyday each of us is exposed to naturally occurring quantities of radiation through the air we breathe, the soil on which we walk the water we drink, the food we eat and even within our bodies ${ }^{[1,2,3]}$.

Furthermore, certain industrial activities such as oil exploration and crude processing, mining result in enhanced Naturally Occurring
Radioactive Materials (NORMs) in the environment $[4,5,6,7,8]$.

The gamma radiation from oil exploration and crude processing arising from inhalation or ingestion of natural radionuclides $[9,10,11,12]$.

The NORMs produced by the oil and gas industry are residues that are enriched with the radium and radon isotopes that originated from the uranium and thorium in the reservoir rocks ${ }^{[13] .}$ 
Worldwide there are more than 40,000 oil and gas fields, many of which are thought to be contaminated with NORMs ${ }^{[14]}$.

Assessment of terrestrial gamma radiation around oil facilities give a better understanding of the causes of fluctuation in dose rates of environmental radiation in the investigated areas and assist in developing a program for radiation protection ${ }^{[15] \text {. }}$

Therefore, many studies have been conducted worldwide to investigate the level of ionizing radiation around oil facilities $[15,16,17,18,19,20]$.

From occupational radiation protection point of view, the current investigation is intended to measure the level of radiation dose and to quantify annual effective dose around five crude oil pumping stations in the Sudan.

\section{Materials and Methods}

\section{2-1 Study area:}

The study area consisted of five pumping station belonging to Petrodar oil company. The pumping station located in four Sudanese state Portsudan and Mosmar (Red sea state), Jabal Um ali (River Nile state), Wd shalayee (White Nile state) and Alelafoon (Khartoum state) as shown in (figure 1).

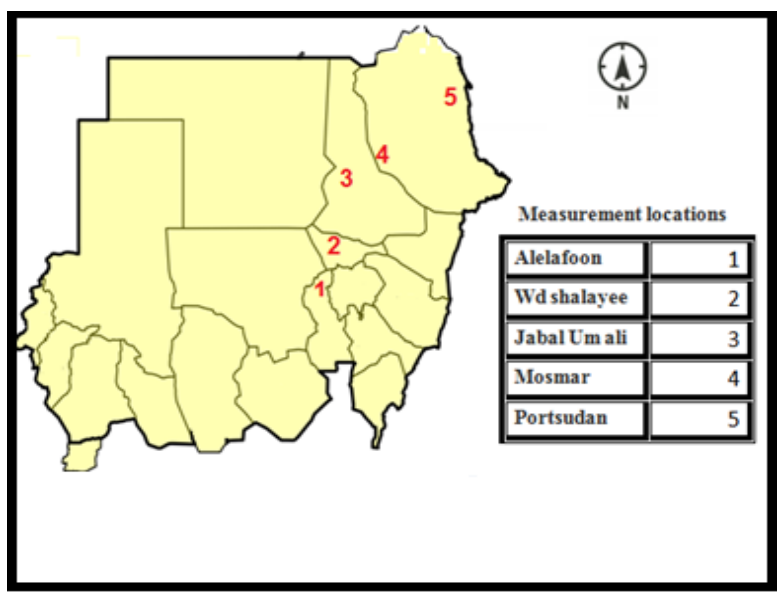

Figure: (1) Map of the study area.

\section{2-3 Experimental procedure :}

Radiation survey meters RDS200 and Polymaster were used to measure radiation dose .The dosimeter RDS200 was previously calibrated at the Secondary Standard Dosimetry Laboratory (SSDL) of Sudan Atomic Energy Commission; calibration factor was $0.88 \mu \mathrm{Sv} / \mathrm{h}$. Background radiations were measured in three different environments far from the area under investigation. The levels of radiation dose were measured at $1 \mathrm{~m}$ above the ground. The gamma dose rates were measured in selected points from receiving pipe, valves, waste area,sludge area and crude tanks.

\section{Results and Discussion}

Figure (2) presents the radiation dose measurements around crude oil pumping stations in the Sudan. The horizontal $\mathrm{x}$-axis represents the location of the measured dose (receiving pipe, valves, waste area, sludge area and crude tanks)

Table (1) shows the statistical summary of radiation dose rate at pumping stations of Petrodar Operating Company .The measured radiation dose at Alelafoon pumping station illustrated in Figure(3). It ranges between $0.03-0.09 \mu \mathrm{Sv} / \mathrm{h}$ with an average value of $0.05 \pm 0.02 \mu \mathrm{Sv} / \mathrm{h}$.

The level of radiation dose at, $\mathrm{Wd}$ shalayee Figure (4) was found to be in range of $0.03-$ 0.09 with an average value of $0.04 \pm 0.01$ $\mu \mathrm{Sv} / \mathrm{h}$ as shown in Table 2. Measured radiation dose at Jabal Um ali figure (5) varied from $0.04-0.07 \mu \mathrm{Sv} / \mathrm{h}$ with an average value of $0.05 \pm 0.01 \mu \mathrm{Sv} / \mathrm{h}$.

The value of radiation dose at Mosmar presented in Fig. (6) ranged from $0.03-0.09$ $\mu \mathrm{Sv} / \mathrm{h}$ with average value of $0.02 \pm 0.03$ $\mu \mathrm{Sv} / \mathrm{h}$. Radiation dose level at Port Sudan 
Figure (7) was found, $0.04-0.10 \mu \mathrm{Sv} / \mathrm{h}$ with average value of $0.07 \pm 0.02 \mu \mathrm{Sv} / \mathrm{h}$.

Spatial distribution of radiation dose measurement has revealed that the highest average of radiation dose was recorded in Port-Sudan station $0.07 \mu \mathrm{Sv} / \mathrm{h}$, while the lowest average radiation dose was measured in Alelafoon station $0.02 \mu \mathrm{Sv} / \mathrm{h}$. The trend of radiation level increases towards downstream and seems to be slightly higher than upstream. This could be attributed to NORM perception and sedimentation in the pipe line and downstream is the area of manifolds, separators, and cleaning/decontamination operations are performed. The level of radiation dose rates in our study seem to be fall far below than those obtained in the Algeria $(0.07-0.8 \mu \mathrm{Sv} / \mathrm{h})$, United Kingdom $(10-300 \mu \mathrm{Sv} / \mathrm{h})$ and USA $(15-100 \mu \mathrm{Sv} / \mathrm{h})^{[8] \text {. }}$

For health risk assessment of radiation dose measurements, the annual effective dose received by workers were calculated by using equation (1).

$$
E=D \times F \times T \times C C
$$

Where $\mathrm{E}(\mu \mathrm{Sv} / \mathrm{y})$ is annual effective dose, $\mathrm{D}$ is absorbed dose rates $(\mu \mathrm{Sv} / \mathrm{h}), \mathrm{F}$ is occupancy factors $(20 \%), \mathrm{T}(\mathrm{h})$ is time to convert from year to hour (8760 hours), and $\mathrm{CC}$ is conversion coefficient ( 0.7 for adults) reported by UNSCEAR to convert absorbed dose in air to the effective dose in human (UNSCEAR).

The average value of annual effective dose at Alelafoon, Mosmar, Portsudan, $\mathrm{Wd}$ shalayee and Jabal Um ali were $6.13,2.45$ ,8.58 4.91 and $6.13 \mu \mathrm{Sv} / \mathrm{y}$ respectively .

Upon comparing the obtained results of radiation dose with global data it was found that the radiation dose is far below the recommended dose level for the public set by International Commission on Radiological Protection which is $1 \mathrm{mSv} / \mathrm{y}$ (ICRP, 2007). Therefore, the radiation dose rate measured around Portsudan, Mosmar, Jabal Um ali, Wd shalayee and Alelafoon are relatively normal as well as the possible radiological effects to workers and public due to oil activity are insignificant.

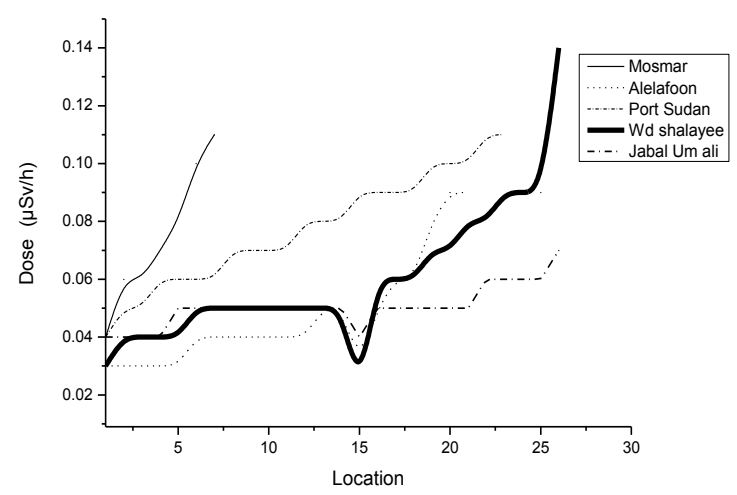

Figure: (2) Distribution of radiation dose at pumping stations.

Table :(1) Statistical summary of radiation dose rate at pumping stations of Operating Company.

\begin{tabular}{llllll}
\hline Location & $\begin{array}{l}\text { No of } \\
\text { samples }\end{array}$ & Min & Max & Average & Std \\
\hline Alelafoon & 20 & 0.03 & 0.09 & 0.05 & 0.02 \\
Mosmar & 7 & 0.03 & 0.09 & 0.02 & 0.03 \\
Portsudan & 23 & 0.04 & 0.10 & 0.07 & 0.02 \\
Wd shalayee & 25 & 0.03 & 0.09 & 0.04 & 0.01 \\
Jabal Um ali & 25 & 0.04 & 0.07 & 0.05 & 0.01 \\
Total & 100 & 0.03 & 0.1 & 0.046 & 0.008 \\
& & & & & \\
\hline
\end{tabular}

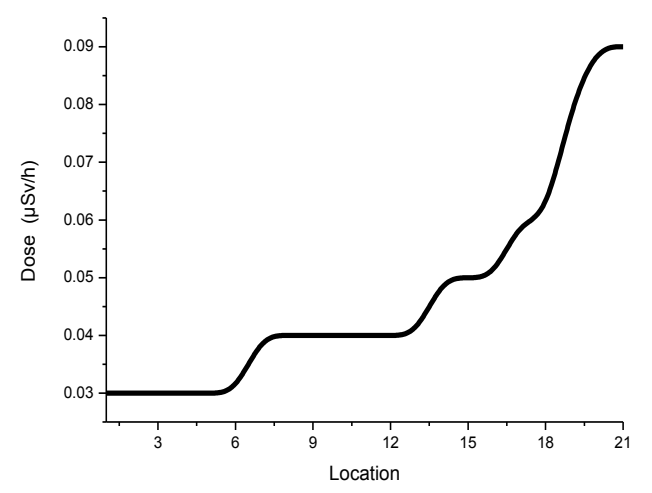

Figure: (3) Distribution of radiation dose at Alelafoon pumping station. 


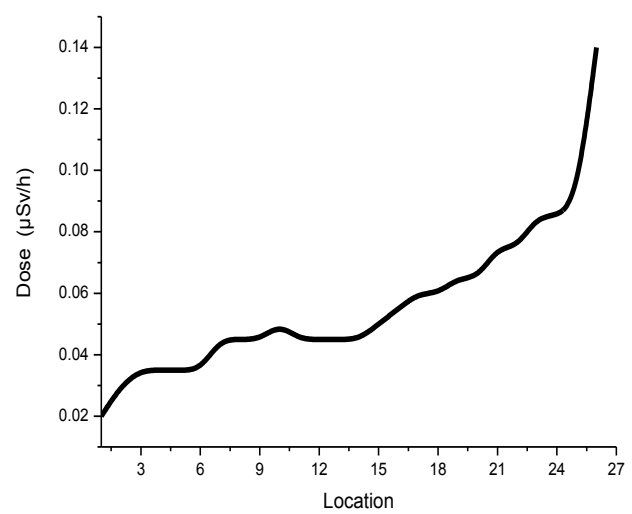

Figure: (4) Distribution of radiation dose at Wd shalayee pumping station.

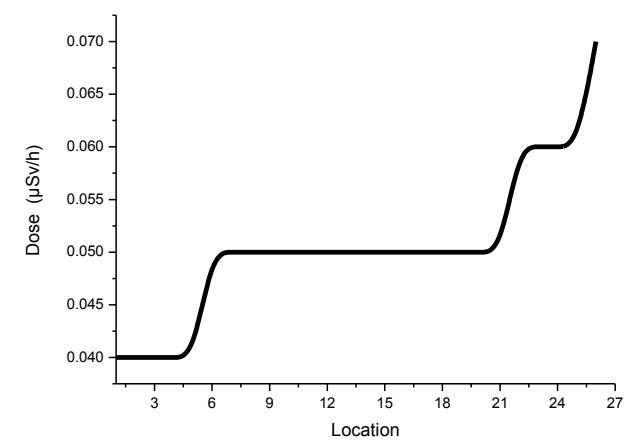

Figure: (5) Distribution of radiation dose at Jabal Um Ali pumping station.

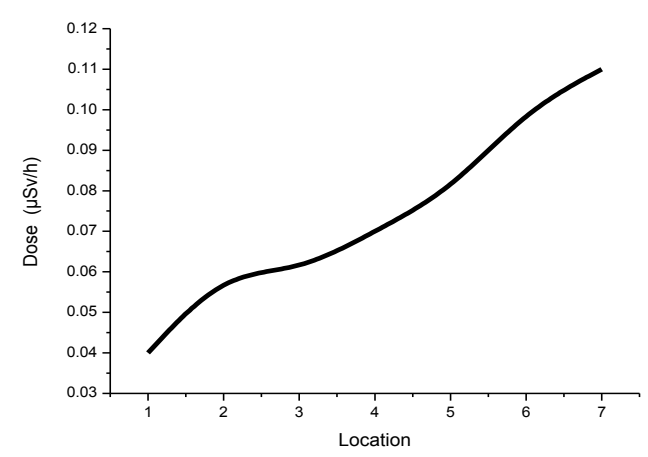

Figure: (6) Distribution of radiation dose at Mosmar pumping station.

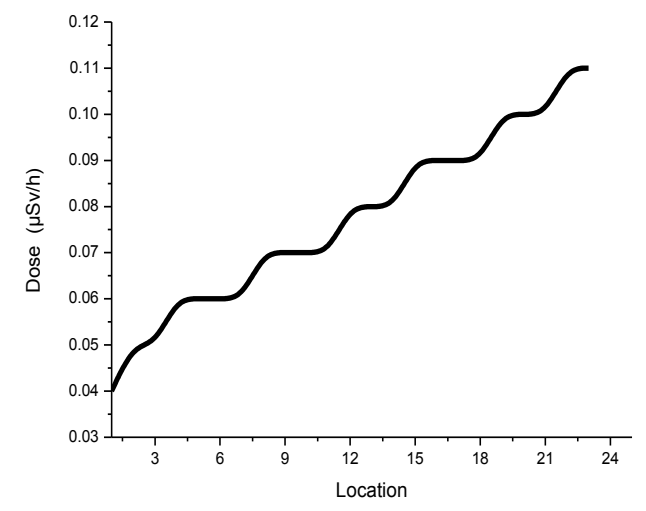

Figure: (7) Distribution of radiation dose at Port Sudan pumping station.

\section{Conclusions}

- The measurement of radiation dose around oil pumping facilities is very important from the viewpoint of environmental radiation protection.

- The radiation dose rate measured around Portsudan, Mosmar, Jabal Um ali, Wd shalayee and Alelafoon are relatively normal. Possible radiological effects to workers and public due to oil activity are insignificant.

\section{Recommendations}

Further studies are needed in order to quantify the concentration of natural radioactivity in waste and sludge areas.

\section{References}

[1] Fadol, Nooreldin, Isam Salih, Hajo Idriss, Ahmed Elfaki, and Adam Sam. Investigation of Natural Radioactivity levels in Soil Samples from North Kordofan State. Sudan." Research Journal of Physical Sciences, r(1)- 2320: 4796(2015).

[2] Hassan, Amna M., Abdelrahman E. Mohamed Osman, Mustafa MO Ahamed, Hajo Idriss, Mohammed A. Eltahir, and Nserdin A. Ragab. Evaluation of Natural Radioactivity Levels in Soil Samples from Eastern and Northern Regions of South Kordofan State, Sudan." Research Journal of Physical Sciences 4(2)2320, 4796 (2016). 
[3] Nooreldin Fadol, Isam Salih, Ahmed Elfaki and Hajo Idriss. Assessment of Natural Radioactivity and Gamma Dose Rate level round Dalani area. South Kordofan Sudan. International Research Journal of Environment Sciences. 5(1), 25-31, (2016).

[4] White, G. J. Naturally Occurring Radioactive Materials (NORM) in oil and gas industrv equipment and wastes (No. DOE/ID/01570-T158). Idaho National Engineering Lab., Idaho Falls, United States (1992).

[5] Jonkers, G., Hartog, F. A., Knaepen, W. A. I., \& Lancee, P. F. J. Characterization of NORM in the oil and gas production (E\&P) industrv. In Radiological Problems with Natural Radioactivity in the Non-Nuclear Industry (Proc. Int. Symp. Amsterdam, KEM A, Arnhem). (1997).

[6] Heaton, B., \& Lambley, J. TENORM in the oil, gas and mineral mining industry. Applied radiation and isotones. 46(6). 577-581 (1995).

[7] Hajo Idriss, Salih, I., Alaamer, A. S., Saleh, A., \& Abdelgali, M. Y. Environmental-Impact Assessment of Natural Radioactivity Around a Traditional Mining Area in Al-Ibedia, Sudan. Archives of environmental contamination and toxicologv. 70(4). 783-792(2016)

[8] Hamlat, M. S., Dieffal, S., \& Kadi, H. Assessment of radiation exposures from naturally occurring radioactive materials in the oil and gas industry. Applied Radiation and Isotopes, 55(1), 141-146. (2001).

[9] United Nations. Scientific Committee on the Effects of Atomic Radiation. Sources and effects of ionizing radiation: sources 1. United Nations Publications (2000).

[10] UNSCEAR. Sources and effects of ionizing radiation, New York, United Nations(1982).

[11] UNSCEAR.Sources and effects of ionizing radiation, New York, United Nations (1988).

[12] UNSCEAR. Sources and effects of ionizing radiation, New York, United Nations (1993).

[13] Xhixha, G., Baldoncini, M., Callegari, I., Colonna, T., Hasani. F.. Mantovani. F.\& Kaceli. M. X. A centurv of oil and gas exploration in Albania: assessment of Naturally Occurring Radioactive Materials (NORMs).Chemosphere, 139, 30-39(2015).

[14] Garner, J., Cairns, J., \& Read, D .NORM in the East Midlands' oil and gas producing region of the UK. Journal of environmental radioactivity, 150, 49-56 (2015).

[15] Bashier, E. H., Salih, I., \& Sam, A. K. GIS predictive mapping of terrestrial gamma radiation in the Northern State, Sudan. Radiation protection Dosimetry 022 (2012).

[16] Agbalagba. E. O.. Avwiri. G. O.. \& Chadumoren. Y. E. Radiological impact of oil and GasActivities in selected oil fields in Production Land Area of Delta State, Nigeria. Journal of Applied Sciences and Environmental Management 17(2), 279-288(2013).

[17] Al Attar. L. Safia. B.. Ghani. B. A.. \& Al Abdulah. J. Recovery of NORM from scales generated by oil extraction. Journal of environmental radioactivity, 153, 149-155(2016).

[18] Gäfvert, T., Færevik, I., \& Rudiord, A. L. Assessment of the discharge of NORM to the North Sea from produced water by the Norwegian oil and gas industry. Radioactivity in the Environment, 8, 193205(2006).

[19] Cowie. M.. Mouslv. K.. Fageeha. O.. \& Nassar, R. NORM Management in the oil and gas industry. Annals of the ICRP, 41(3), 318-331(2012).

[20] Garner, J., Cairns, J., \& Read, D. NORM in the East Midlands' oil and gas producing region of the UK. Journal of environmental radioactivity,150, 49-56(2015). 


\section{المسح الإشعاعي حول محطات ضنخ النفط الخام في السودان

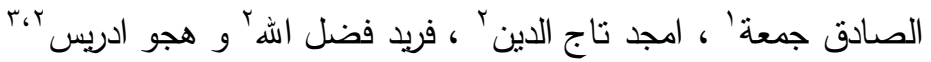

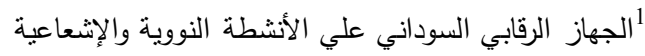 \\ بهيئة الطاقة الذرية السودانية}

3 اللجنة الدائمة للوقاية من الإشعاع والتلوث البيئي جامعة الإمام محمد بن سعود الإسلامية - الرياض -المملكة السعودية

الجهاز الرقابي السوداني علي الأنشطة النووية و الإشعاعية، بريد الكتروني: Sadiggumaa@gmail.com

المستخلص. السلامة والصحة في مكان العمل مهمة من أجل رفاهية كل من العمال والجمهور. لذلك تم إجراء

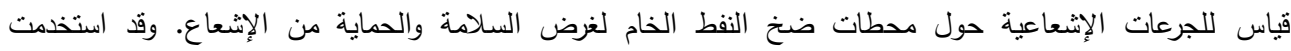
كواشف الرادوز -.. ب والبوليماستز لقياس الجرعة الإشعاعية. وأظهر نزتيب مستوى الإشعاع في مناطق الدراسة الاتجاه التالي: بورتسودان> العيلفون = جبل أم علي> ود شعلي > مسمار • تم مقارنة متوسط مستوى الجرعة الإشعاعية للاراسة ع 7, م مايكروسفرت/سنة مع المستويات الموصي بها من قبل المنظمات الدولية المعنية بالسلامة من الإشعاع. وجد أن الجرعة السنوية الفعالة ضئيلة مقارنة مع الحد المسموح به من اللجنة الدولية للوقاية الإشعاعبة .,. ملي سيفرت / سنة. و من منظور صحي خاص بالإنسان، وأظهرت هذه الدراسة أنه لا توجد مخاطر صحية محتملة للعمال والجمهور بسبب التعرض الإشعاعي.

كلمات مفتاحية: الإثعاع ،الجرعة السنوية الفعالة ، رادوز -... ، ، النفط الخام ، محطات الضخ 